S $4-01$

$$
\text { ピアニストの手の動作解析 }
$$

\title{
○酒井直隆，腰野富久（横浜市立大学医学部整形外科）
}

Fong-Chin Su, Michael C Liu, Allen T Bishop, Kai-Nan An

(Mayo Clinic 整形外科バイオメカニクス研究所)

\section{Hand motion analysis of the pianist.}

\section{Naotaka Sakai, Tomihisa Koshino}

(Dept. of Orthopaedic Surgery, Yokohama City Univ. Sch. of Med.)

Fong-Chin Su, Michael C Liu, Allen T Bishop, Kai-Nan An

(Orthopedic Biomechanics Lab., Mayo Clinic)

\section{1.はじめに}

楽器の演奏に際して演奏者が要求される手 指の運動は極的て複雑かつ敏捷で、しかも楽 器の種類によって動作内容が著しく異なる特 色を持っている。例えばピアニストは両前腕 を回内して手掌を键盤に向け、各指をアーチ 型に保ちながら打鍵するのが原則だが、同じ ピアノを弾く動作でも、単純な音階を弾く場 合と、和音やオクターウ、アルペジオ等のテク ニックによって異なるし、強弱や音色を変え る場合も各関節の動きは微妙に異なってくる。 楽曲を演奏する場合は、様々なテクニックや タッチが動員されるため、その演奏を解析し ても対象間等で比較検討することは困難であ る。

しかし一見複雑そうに見えるピアノ演奏も、 基本となるテクニックを選んで一定のテンポ で反復演奏させれば、ピアノを弾く動作を単 純化することができる。この観点から我々は、 反射性マーカーのビテオ画像をコンピュータ 一によって解析する方法で、ピアニストの手 指の動作解析を試み、椅子の高さが手の運動 に及ぼす影䭗についても併せて検討したので 報告する。

\section{2. 対象亡方法}

対象は 10 人のピアニストで、男 4 人・女 6
人であり、平均年齡は 29.1 歳（24歳～39歳） であった。

動作解析システムはExpert Vision System (Motion Analysis社)を使用した")（図1）。 このシステムは C C Dカメラで撮影した反射 性マーカーの画像から各マーカーの三次元座 標を計算し、さらにマーカーのなす直線や平 面間の角度を各フレーム毎に求めるものであ る。

マーカーは值径 $3 \mathrm{~mm}$ の反射性マーカーを使 用し、これをピアニストの右中指の末節（図 2のM1）、D I P 関節 (M 2) 、中節 (M 3 ）、基節 $(M 4 ， 5)$ 、右手背 (M 6， 7, 8）および右前腕伸側（M9，10，11）に計 11個を両面粘着テープで固定した。M 1 から M 6 までの 6 個のマーカーは中指中線上およ びその延長線上に並ぶようにし、M 6、7 は 第 2、3 中手骨顠部のYP関節より $5 \mathrm{~mm}$ 近位の 位置に固定した。M 9 は樈骨茎状突起上、M 10は尺骨茎状突起上に固定し、M 8 はM 6 、 7 とM 9、10の中間でM 1 から 6 を貫く直線 上の位置に固定した。

赤色のリングライトを取り付けた N E C 社 製 C C Dカメラ 4 台を設置し、今回の動作解 析用に作製した高さ $40 \mathrm{~cm}$ 、幅 $30 \mathrm{~cm}$ 、奥行き 30 cmのキャリフレーション・フレーム（直径 


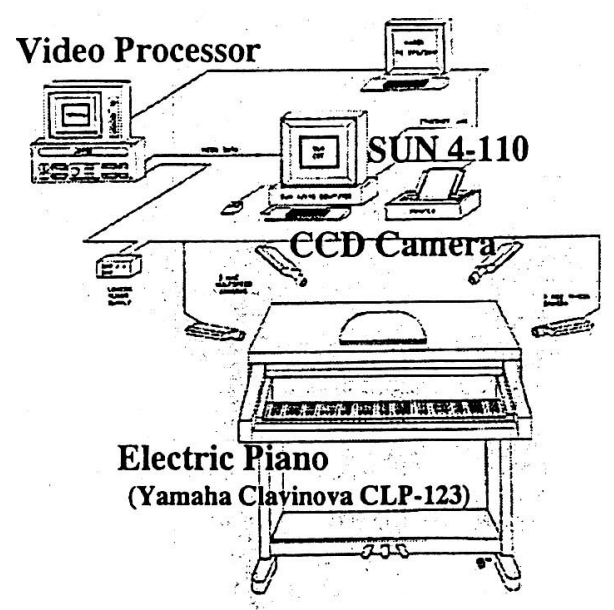

図 $1:$ Expert Vision System

電子ピアノ前上方に設置した 4 台のC C D カメラで撮影したマーカーの画像をコンピュ 一ターで解析した。

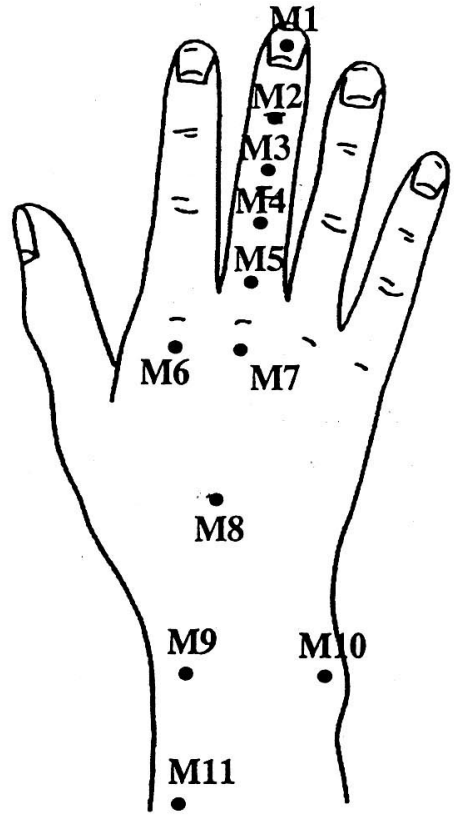

図 2 : 反射性マーカーの位置

右中指背側・右手背に直径 $3 \mathrm{~mm}$ 、計11個の 反射性マーカーを張り付けた。
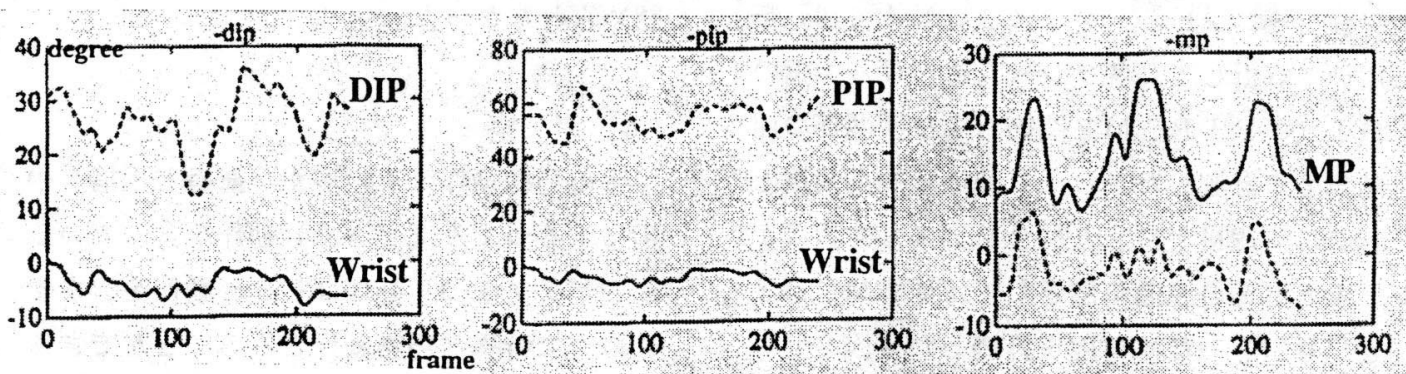

図 3 : 音階演奏時の右中指D I P、P I P、M P 関節之手関節（Nrist）の変化

毎秒60フレーム、計240フレームにおける各関節の屈曲角度変化を示す。音階演奏では $\mathrm{MP}$ 関節が周期的に屈曲し、打鍵した瞬間D I P 関節の屈曲が減少したが、他の P I P 関節および 手関節には大きな変化はなかった。
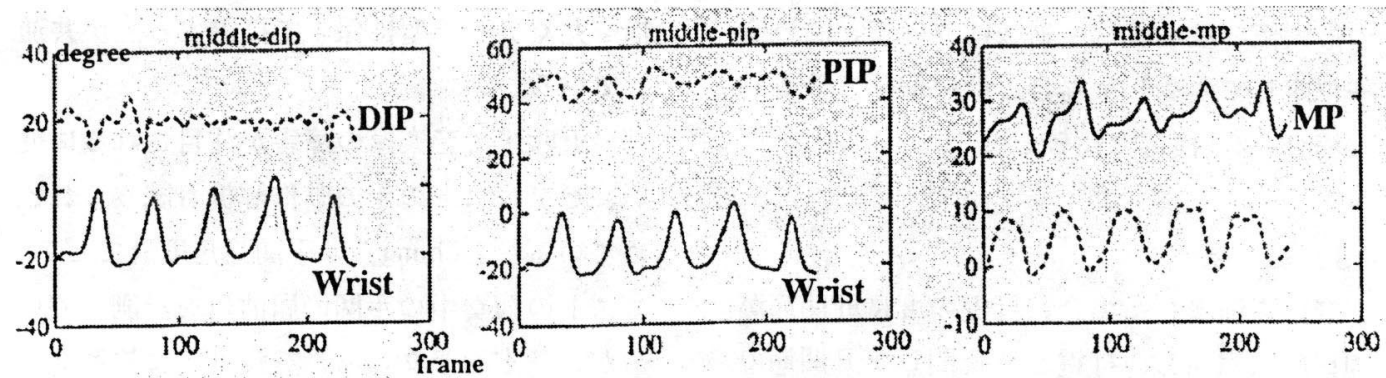

图 4 ：和音演奏時の右中指D I P、P I P、MP関節之手関節（Nrist）の変化

和音演奏では手関節が周期的に風曲し、M P 闺節および D I P 関節は音階の時ほよ゙の変化を 示さなかった。 
2.5インチの反射性マーカーを $4 \times 4=16$ 個 使用）を用いてまずキャリブレーションを行っ た。次いで、電子ピアノ(ヤマハ社製クラビ ノーバC L P - 123）を設置して、上記の反射 性マーカーを右手に付けたピアニストに演奏 させた。ピアノ演奏は、基本的な八長調音階 (ド・レ・ミ・ファ・ソ・ファ・ミ・レ・ド) を毎分120拍の速度で、八長調和音（ドミソ） を毎分80拍の速度で演奏させた。音階では 1 指から 5 指までの各指で交互に打鍵させ、和 音は1・3・5指でド・ミ・ソの鍵盤を同時に 打鍵させた。演奏に際しては、ピアニストを 床からの高さが $56.5 \mathrm{~cm}$ の高い椅子と、高さ $41.5 \mathrm{~cm}$ の低い椅子に座らせ、椅子の高さのピ アノ演奏に及ぼす影響を検討した。

C C D カメラによる撮影は毎分60フレーム で 4 秒間、計 240 フレーム行い、このデータ をビデオ・プロセッサーおよびワークステー ション・コンピューター（ＳUN 4-110）を 用いて解析して、各フレームにおける中指の D I P、P I P、M P 関節および手関節の屈 曲角度を計测した。D I P 関節の屈曲角度と しては直線M 1 M 2 とM 2 M 3 のなす角度を、 P I P 関節の屈曲角度としては直線 M $2 \mathrm{M} 3$ とM4M 5 のなす角度を計湘した（図2）。 M P 関節の屈曲角度としては、直線M 4 M 5 と平面M $6 \mathrm{M} 7 \mathrm{M} 8$ のなす角度を、手関節の 屈曲角度としては、平面 M $6 \mathrm{M} 7 \mathrm{M} 8$ と平面 M 9 M10M11のなす角度を計測した。各角度 の最大値、最小値、可動域について、高い椅 子に座って演奏した場合と低い椅子で演奏し た場合とを検定で比較した。

\section{3. 結 果}

音階を演奏した場合、打鍵の度にMP関節が 周期的に屈曲し、打鍵した瞬間D I P 関節の 屈曲角が減少したが、他のP I P 関節および 手関節には大きな変化はなかった（図3）。
一方の和音演奏では、打鍵の度に手関節が 周期的な屈曲を繰り返し、M P 関節および D) I P 関節は音階の時ほどの変化を示さなかっ た（図4）。

音階演奏時の手関節の最小屈曲角は高い椅 子に座った時が-17.4 $48.4^{\circ}$ で、低い椅子に座っ た時の $-5.1 \pm 6.3^{\circ}$ より有意に $(\mathrm{p}<0.01)$ 小 さかった。また音階演奏時の手関節最大屈曲 角も、高い椅子に座った時が-5.8 $87.0^{\circ}$ で、 低い椅子に座った時の7. $2 \pm 9.5^{\circ}$ より有意に $(p<0.01)$ 小さかった。和音演奏時も同様 で、高い椅子に座った場合が低い椅子よりも 最大・最小屈曲角が各々有意に $(\mathrm{p}<0.01)$ 小さかった。音階・和音ともに手関節の可動 域には有意差は見られなかった。

D I P、P I P、M P関節の最大・最小屈 曲角および関節可動域については、音階・和 音のいずれの演奏時でも、両群間に有意差は 認められなかった。

\section{4. 考 察}

手の巧緻動作はその多くが拇指と示指・中 指によるつまみ（ピンチ）動作を含んでいる が、ピアノを弾く動作はピンチ動作を含まず、 この点で特異な巧緻動作とみることができる 4)。複数のキーを吒いて機械を操作するキー ボード操作はピアノばかりでなく、計算機や タイプライター、ワードプロセッサーでも見 られ、前腕を回内して手関節を軽度屈曲させ、 指を丸くアーチ型に保って打鍵する点が共通 している。

最近欧米で音楽家の障害が注目されるに従 い、ピアニストの手の動作解析も試みられ始 めている5)。Chungらは手関節角度計でピア ニストの演奏中の手関節屈曲角を計測してい るが、基本的テクニックを選ばずに複雑な楽 曲そのものをピアニストに演奏させ、しかも 計測が手関節のみにとどまっている点で、ピ 
アノ演奏の詳細な解析を行ったとは言い難い 3)。Hardingらは2 台のビデオカメラで撮影 した画像を元に、ピアニストの各指関節の力 学的解析を試みているが、手関節の動作が解 析できぬ上に、指が回旋した場合の測定精度 に問題があると思われる ${ }^{4}$ 。我々は、手指 の巧絰動作において手関節および各指関節が 連動している点を重視し、これらの関節の角 度変化が演奏の最中でも同時に解析できるシ ステムを試作した。この試作の過程で各種の 大きさの反射性マーカーを製作して比較した が、結局直径 $3 \mathrm{~mm}$ のものが C C D メラの解 像度に適い、測定誤差も少ないことを知り得 た。本システムではＣＣＤカメラを設宜する ポジションも問題となるが、幸いにもキーボ 一ド操作では拇指が対立位をとることが少な く、4台のカメラを前上方に設置することで 解析を行うことができた。

音階と和音はピアノのテクニックの中でも 最も基本的なものだが、今回この 2 つのテク ニックを解析して比較してみると、音階が主 にMP関節の屈伸で弾かれているのに対し、 和音は手関節の屈伸が主体で、テクニックの 種類によって手関節を含めた手の使い方が大 きく異なっていた。このことは同じピアノの 鍵盤上の打鍵動作でも、テクニックの種類に よって各関節の使い方が異なることを示して おり、手指の巧篦動作の多様さを示したもの と考えられる。

一方、椅子の高さの影響については、音階 之和音の動作で上記のような相違があるにも かかわらず、手関節の最大・最小屈曲角にお いてのみ両群間に有意差が認められたことは 興味樑い事実である。椅子の高さの変化は肩 および肘の高さの変化をきたし、これが前腕 のキーボードに対する傾斜角を変化させるが、 今回の結果から、ピアニストは前腕の傾斜角 の变化を手関節のみで調節し、各指闵節は一
定に保たれていることを知り得た。このこと はピアノ演奏では M P 関節以遠の関節角度を 一定に保つこと、すなわち指のアーチの形状 を一定に保つことが、極めて重要な要素であ ることを伺わせた。

\section{5.まとめ}

1 ) 直径 $3 \mathrm{~mm}$ の反射性マーカーとExspert Vision Systemを使って、ピアニストの手指 の動作解析を行った。

2 ）音階演奏ではM P 関節の屈伸が、和音で は手関節の屈伸が主体となっており、テクニッ クの種類によって手指動作は異なっていた。

3 ) 椅子の高さを変化させると、手関節のみ が変化して前腕の傾斜角の変化を調節してお り、他の指関節には影響が見られなかった。

\section{参考文献}

1) An KN, Growney E, Chao EYS:

Measurement of joint kinematics using expertvision system. Biomechanical Sciences Instrumentation. 27:245-252, 1991.

2) Chung IS, Ryu J, Ohnishi N, Rowen B, Headrich $\mathrm{J}$ : Mrist motion analysis in pia nists. Med Probl Perform Art, 4:109-113, 1989.

3) Harding DC, Brandt KD, Hillberry BM : Minimization of finger joint forces and tendon tensions in pianists. Med Probl Perform Art, 4:103-108, 1989. 4) Kapandi i IA: The physioogy of the joints. vol:upper limb. pp256-279, Churchill Livingstone, London, 1982.

5) Sakai N: Hand pain related to keyboard techniques in pianists. Med Probl Perform Art, 7:63-65, 1992. 